\title{
Differential Expression of Zymomonas mobilis Sucrase Genes (sacB and sacC) in Escherichia coli and Sucrase Mutants of Zymomonas mobilis
}

\author{
Sangiliyandi Gurunathan ${ }^{1 *}$ and Paramasamy Gunasekaran ${ }^{2}$ \\ ${ }^{I}$ Department of Cell and Developmental Biology; School of Medicine; University of North Carolina at Chapel Hill; \\ Chapel Hill NC 27599-7090; 108, Issac M Taylor Hall; North Carolina - USA. ${ }^{2}$ Department of Microbial \\ Technology; School of Biological Sciences; Madurai Kamaraj University; Madurai 625 021; India
}

\begin{abstract}
The sacB and sacC genes encoding levansucrase and extracellular sucrase respectively were independently subcloned in pBluescript (high copy number) and in Z. mobilis-E. coli shuttle vector, pZA22 (low copy number). The expression of these genes were compared under identical background of E. coli and Z. mobilis host. The level of $s a c B$ gene expression in E. coli was almost ten fold less than the expression of sacC gene, irrespective of the growth medium or the host strain. In Z. mobilis the expression of sacB and sacC genes was shown to be subject to carbon source dependent regulation. The transcript of sacB and sacC was three fold higher in cells grown on sucrose than in cells grown on glucose/fructose. Northern blot analysis revealed that the transcript levels of sacC was approximately 2-3 times higher than that of sacB. These results suggested that the expression of sacC gene was more pronounced than sacB.
\end{abstract}

Key words: Zymomonas mobilis, Escherichia coli, Expression, Levansucrase, Extracellular sucrase

\section{INTRODUCTION}

Zymomonas mobilis, a gram negative bacterium, has been shown to produce ethanol at a rate three to four fold, and at a higher final yield compared to the traditionally used yeast strains (Rogers et al., 1982). However, this organism uses only a narrow range of substrates, which is limited to glucose, fructose and sucrose (Swings and DeLey, 1977). However, when grown on media containing sucrose as the carbon source, the ethanol yield is considerably reduced because of the by products formed such as levan, fructo-oligomers and sorbitol (Viikari, 1984). When Z. mobilis is grown on sucrose medium, extracellular sucrose hydrolyzing enzymes such as intracellular sucrase (SacA or InvA), extracellular levansucrase (SacB or Inv C) and extracellular sucrase (SacC or InvB), are produced. The SacA enzyme is a monomer with a molecular weight of $58 \mathrm{kDa}$. The sacA gene from Z. mobilis has been cloned, sequenced and characterized (Gunasekaran et al., 1990a). The deduced amino acid sequence of sacA gene product showed strong homology with the intracellular sucrase of Bacillus subtilis and yeast invertases. The intracellular sucrase SacA from $Z$. mobilis was purified to homogeneity from a recombinant $E$. coli strain containing the sacA gene under an expression system. The protein was monomer with a molecular mass of $58 \mathrm{kDa}$. The

\footnotetext{
* Author for correspondence
} 
sucrase activity was maximal at $25^{\circ} \mathrm{C}$ and thermal stability of the purified protein was low and maximal activity was at $\mathrm{pH} 6.5$ Therefore, SacA alone is unable to support the growth of $Z$. mobilis on sucrose (Ait-Abdelkader et al., 2000).

Levansucrase, a beta-fructo-furanosidase, is an extracellular enzyme that is responsible for both sucrose hydrolysis and levan formation. Levansucrase has been purified from Z. mobilis cells (Lyness and Doelle, 1983) and from culture broth (Mortatte et al., 1983). It is a monomer with a molecular weight of $51 \mathrm{kDa}$ in Z. mobilis ZM4 (Preziosi et al., 1990b). The SacB enzyme purified from culture filtrate of Z. mobilis Z6C has a molecular weight of $56 \mathrm{kDa}$ (Yanase et al., 1992). The gene encoding ( $(a c B)$ levansucrase and $(s a c C)$ in Z. mobilis NRRL B.806 and ATCC10988 has been cloned and sequenced (Gunasekaran et al., 1995). Recently, the over expressed levansucrase (SacB) was purified from the recombinant E. coli by a simple method and characterized (Sangiliyandi and Gunasekaran, 1998). A levansucrase (SacB) was purified to elecrophoretic homogeneity from a recombinant $E$. coli. The 55 $\mathrm{kDa}$ enzyme hydrolyzed $\beta$-fructosides but not $\alpha$ glucosides and catalysed levan formation from sucrose as well as raffinose. The optimum temperature for polymerase activity was at $30^{\circ} \mathrm{C}$ and hydrolase activity at $50^{\circ} \mathrm{C}$. However, the polymerase activity was selectively abolished by para-chloromercuribenzoate (Sangiliyandi et al., 1999a) and also by in-vitro mutagenesis (Sangiliyandi et al.,1999b). Recently, a levansucrase mutant was isolated by in-vitro mutagenesis using hydroxylamine. By mutation in the protien, the levanforming activity was abolished but the sucrase activity was retained in the mutant strain. This uncoupling of the sucrase activity from the levan-forming activity suggests a change in the protein conformation due to mutation and elevated temperature could have led to the loss of activity (Sangiliyandi and Gunasekaran, 2001).

An extracellular sucrase (Sac C or InvB) has a high specific activity for sucrose hydrolysis. Nearly this enzyme contributes $60 \%$ of the extracellular sucrase activity. However, it catalyses neither fructose polymerization into levan nor degradation of polyfructose such as levan or inulin. Thus this enzyme differs from the B. subtilis SacC, which shows levanase activity in addition to sucrose hydrolysis (Kannan et al.,
1995). The purified active enzyme from Z. mobilis strain CP4 is a monomer with a molecular weight of 46-47 kDa (O Mullan et al., 1992). The sacC gene was cloned and expressed in E. coli (Kannan et al., 1995). The overexpressed extracellular sucrase of $Z$. mobilis was purified from a recombinant $E$. coli by repeated cycles of freezing and thawing, followed by hydroxyapatite column chromatography. The purified enzyme had a $\mathrm{Mw}$ of $46 \mathrm{kDa}$, as determined by SDS-PAGE. Its $\mathrm{km}$ value for sucrose was $86 \mathrm{mM}$ and had an optimal $\mathrm{pH}$ and temperature at 5.0 and $36^{\circ} \mathrm{C}$ respectively (Sangiliyandi and Gunasekaran, 2000). Here we show the differential expression of levansucrase and extracellular sucrase activity of $Z$. mobilis sucrase genes in E. coli and Z. mobilis hosts.

\section{MATERIALS AND METHODS}

\section{Bacterial strains and plasmids}

Escherichia coliJM109 (RecA1, endA1, gyrA96 thi, hsdR17, SupE, relAl(lac proAB) $\left[F^{\prime}\right.$ traD36 proAB, lacIq, $\triangle M 15]$ BL21(DE3) $\mathrm{F}^{-}$hsdS gal (r'm ) lon ompT. XL1 Blue EndA1 hsd17 $\left(r-m^{+}\right)$supE44 thi-1 A-gyrA96 recAl $\triangle$ lac ( $F$ ' proAB lacIq $4 M 15$ Tn10). Plasmid pBluescript $\mathrm{KS}^{+}$(Stratagene, USA). Z. mobilis wild type (NRRL B-806). The recombinant plasmid pLSS41 carrying $5 \mathrm{~kb}$ chromosomal DNA fragment coding for $s a c B$ and sacC of Z. mobilis. Plasmid pRK2013 was used as a helper for conjugations.

\section{Growth conditions}

Z. mobilis strains were grown in complete media $\mathrm{RM}$ containing (per liter) glucose $20 \mathrm{~g}$, yeast extract $10 \mathrm{~g}, \mathrm{KH}_{2} \mathrm{PO}_{4} 2 \mathrm{~g}$ and $\mathrm{pH}$ adjusted to 6.0. Whenever necessary, different carbohydrate sources such as glucose (RMG) or fructose (RMF) or sucrose (RMS) was added to RM. The cultures were grown at $30^{\circ} \mathrm{C}$ at static condition. E. coli strains were grown at $37^{\circ} \mathrm{C}$ under agitation in $\mathrm{LB}$ or M63 medium.

\section{Construction and screening of recombinant sucrase clones}

A $1.7 \mathrm{~kb}$ DraI fragment containing an ORF encoding levansucrase $(\mathrm{SacB})$ from the plasmid pLSS41 was purified by the method of Suzuki et al. (1991) and then ligated with EcoRV digested pBluescript $\mathrm{KS}^{+}$. The resultant plasmid $\mathrm{pLS} 3$ had only $s a c B$ gene located downstream of the $\mathrm{T} 7$ 
promoter in the pBluescript $\mathrm{KS}^{+}$. This recombinant plasmid was transformed into E. coli JM109. A 2.1 $\mathrm{kb} P v u$ II fragment containing an ORF encoding levansucrase (SacB) from the plasmid pLS3 carrying $\mathrm{S} a c B$ was purified and cloned into Eco RV site in the shuttle vector pZA22. The resultant plasmid was designated as pLSP13. A $2.1 \mathrm{~kb} P v u$ II fragment containing an ORF encoding extracellular sucrase $(\mathrm{SacC})$ from the plasmid pLSS41 carrying sacC was purified and cloned into the Eco RV site of pBluescript $\mathrm{KS}^{+}$. The resultant plasmid was termed pZS63. A $2.1 \mathrm{~kb} P v u$ II fragment containing an ORF encoding extracellular sucrase $(\mathrm{SacC})$ from the plasmid pLS63 carrying sacC was purified and cloned into the Eco RV site of the shuttle vector pZA22. The resultant plasmid was termed pZSP62.

\section{Assay of levansucrase activity}

Sucrose hydrolyzing and levan forming activities were assayed as previously described (O' Mullan et al., 1992). Levan was estimated by hydrolyzing the levan in $0.1 \mathrm{~N} \mathrm{HCl}$ at $100{ }^{\circ} \mathrm{C}$ for $1 \mathrm{~h}$ according to Viikari and Gisler, (1986) and expressed as fructose units. One unit of levan forming activity of the levansucrase was defined as the amount of enzyme required to produce $1 \mu$ mole of levan (as fructose units) in one minute. One unit of sucrose hydrolysing activity of the levansucrase was defined as the amount of enzyme releasing 1 $\mu$ mole of reducing sugar per minute. The protein concentration was determined by the method of Lowry et al. (1951).

\section{Recombinant DNA techniques}

Preparation of plasmid DNA was carried out by standard method (Sambrook et al.,1989). Purified plasmid was obtained using plasmid purification kit (Qiagen Inc., USA). The DNA fragments were separated as mentioned by Suzuki et al. (1991). All cloning experiments were carried out according to standard methods (Sambrook et al., 1989). Transformation was performed as described by Chung and Miller, (1988).

\section{Bacterial conjugations}

Bacterial conjugations were performed by triparental filter matings as previously described (Arvanitis et al., 2000). For counter selection against donor cells, $100 \mathrm{mg} / \mathrm{ml}$ nalidixic acid was used for ATCC 10988. All transconjugants were tested for their plasmid content with plasmid isolation, back transformation, and restriction analysis.

\section{Dot Blot hybridization}

Northern Dot Blots containing upto 5ug of alkaline -denatured total RNA were prepared using $9 \times 12 \mathrm{~cm}$ Zeta Probe GT Nylon membranes and a Bio Dot SF Microfiltration apparatus (Bio-Rad 170-6543). Membranes were hybridized using Express Hyb Hybridization solution (Clontech), and DNA probes end radiolabeled by using ( $\gamma 32 \mathrm{P})$ dATP $(3000 \mathrm{Ci} / \mathrm{mmol})$ or by direct incorporation using ( $\alpha-32 \mathrm{P}) \mathrm{dCTP}(3000 \mathrm{Ci} / \mathrm{mmole})$ Amersham redivue). Membranes were washed twice for $30 \mathrm{~min}$ at $61^{\circ} \mathrm{C}$ in $1 \mathrm{mM}$ EDTA, $40 \mathrm{mM} \mathrm{NaHPO}$, $\mathrm{pH} \quad 7.2$ and $5 \%$ according manufacturers instructions. RNA signal in the same sample using phosphorimager analysis and the data acquisition packages provided with instrument.

\section{Northern Blot hybridization}

Total RNA of Z. mobilis and E. coli was isolated as described previously (Ausubel et al., 1994). Samples $(5 \mu \mathrm{g})$ were electrophoresed on a $0.8 \%$ agarose-formaldehyde gel and transferred to a nylon membrane filter (Schleicher and Schuell). Pre-hybridization and hybridization was carried out in hybridization solution $(50 \%$ formaldehyde, $5 \mathrm{x}$ Denhardt reagent, $50 \mathrm{mM}$ sodium phosphate (pH5.5), $120 \mathrm{mM} \mathrm{NaCl}, 0.1 \%$ SDS, $125 \mathrm{~g}$ of sonicated salmon sperm DNA per $\mathrm{ml}$ ) at $50^{\circ} \mathrm{C}$. The gene specific probes were labeled with random-primed labeling kit (Boehringer Mannheim). Filters were washed twice at room temperature and twice at $65^{\circ} \mathrm{C}$ in $2 \mathrm{X}$ SSC- $0.5 \%$ SDS and then washed once at room temperature in $0.1 \mathrm{x}$ SSC. These filters were exposed to X-ray films.

\section{RESULTS AND DISCUSSION}

Subcloning of sucrase genes of $Z$. mobilis in $E$. coli

In order to study the promoter strength of levansucrase and extracellular sucrase genes, the $s a c B$ gene and $s a c C$ gene were cloned and expressed in E. coli. Z. mobilis chromosomal DNA fragment (a $5.0 \mathrm{~kb}$ HindIII fragment) present in the plasmid pLSS41 possess ORF1 and ORF2 that encoded extracellular levansucrase (SacB) and extracellular sucrase (SacC) respectively 
(Gunasekaran et al., 1995). The levansucrase gene $s a c B$ resides within the two $D r a \mathrm{I}$ restriction sites separated by $1.7 \mathrm{~kb}$. The purified $1.7 \mathrm{~kb}$ fragment was cloned into EcoRV site of pBluescript $K S^{+}$. The ligated mixture was used to transform E. coli JM109. The transformants were selected on LB agar containing ampicillin $(20 \mathrm{mg} / \mathrm{l})$, IPTG (40 $\mathrm{mg} / \mathrm{l})$ and X-gal $(20 \mathrm{mg} / \mathrm{l})$ by Blue-white selection. All the white colonies were scored as recombinant clones. The recombinant clones were independently grown in M63 medium supplemented with glycerol $(1 \% \mathrm{v} / \mathrm{v})$, cell lysate was prepared and assayed for both sucrose hydrolyzing activity and levan forming activity. The cellular fractions of all recombinant clones exhibited sucrase activity and levan forming activity on standard plate screening. Plasmid was isolated from a recombinant clone and was designated as pLS3. The plasmid pLS3 was used to transform E. coli JM109. All the transformants exhibited levansucrase positive phenotype i.e. sucrose hydrolyzing and levan forming activities, confirming the plasmid pLS3 carried DraI fragment encoding levansucrase. The same selection procedure was followed for screening of pZS63 plasmids.

$2.1 \mathrm{~kb} P v u$ II fragment in pLS3 carrying $s a c B$ was isolated and cloned into EcoRV digested pZA22. The ligated mixture was used to transform $E$. coli JM109. Transformants were selected on LB agar containing $\mathrm{Cm}(30 \mu \mathrm{g} / \mathrm{ml})$ and replica plated on LB agar containing Tc $(15 \mu \mathrm{g} / \mathrm{ml})$. The $\mathrm{Cm}^{\mathrm{r}} \mathrm{Tc}^{\mathrm{s}}$ colonies were selected as recombinant clones and were analyzed for levansucrase activity. Plasmid from one of the levansucrase positive clone was isolated and designated as pLSP13. For subcloning of $s a c C$ gene, a $2.1 \mathrm{~kb} P v u \mathrm{II}$ fragment from pZS63 was isolated and ligated with EcoRV linearized pZA22. The ligation mixture was used to transform E. coli JM109. Transformants were selected on LB Cm $(30 \mu \mathrm{g} / \mathrm{ml})$ plates, replica plated on LB Tc plates and tested for sucrose hydrolysis activity as described earlier. One of the sucrase positive clones carried a recombinant plasmid, designated as pZSP62. The presence of the $2.1 \mathrm{~kb}$ insert in this plasmid was confirmed by restriction analysis. This plasmid was $8.8 \mathrm{~kb}$ in size and carried $s a c C$ gene downstream to $\mathrm{T} 7$ promoter.

\section{Expression of Sucrase genes in $\boldsymbol{E}$. coli}

The plasmids pLSP13 and pZSP62 (in pZA22, shuttle vector) were separately transferred into the E. coli strains JM109 and XL1Blue in which the $s a c B$ and $s a c C$ genes use their own promoter for expression. Comparison of the recombinant strains grown in LB medium revealed that the $E$. coli strain carrying $s a c B$ gene exhibited sucrase activity of $0.24-0.27 \mathrm{U} / \mathrm{mg}$ while the strains carrying $\mathrm{sacC}$ gene exhibited sucrase activity of 3.03-3.10 U/mg. Similar comparison of the strains grown in M63 medium showed that the sucrase activity of the strain carrying cloned $s a c B$ gene was $0.60-0.63 \mathrm{U} / \mathrm{mg}$ while the strain carrying cloned $\mathrm{sacC}$ gene expressed an activity of 7.04$7.10 \mathrm{U} / \mathrm{mg}$. These results suggested that, the level of $s a c B$ gene expression in E. coli was almost ten fold less than the expression of $\mathrm{sacC}$ gene, irrespective of the growth medium or the host strain (Fig .1.)

The plasmids pLS3 and pZS63 (in pBSKS ${ }^{+}$) were independently transferred into $E$. coli strains and the expression of $s a c B$ and $s a c C$ genes were studied under the conditions of with and without IPTG. The cloned genes were expressed using T7 as well as the native promoter in E. coli. Analysis of the LB grown cells revealed that E. coli (pLS3) produced a low level of sucrase activity $(0.56-$ $0.60 \mathrm{U} / \mathrm{mg}$ ) than the E. coli (pZS63) $(5.79-5.80$ $\mathrm{U} / \mathrm{mg}$ ). Comparison of the cells grown in different media revealed that the M63 medium grown cells produced higher level of sucrase activity. In this medium, the $s a c B$ gene carrying cells produced sucrase activity of $1.12-1.20 \mathrm{U} / \mathrm{mg}$ while the $\mathrm{sacC}$ gene carrying strains exhibited sucrase activity of $9.15-9.20 \mathrm{U} / \mathrm{mg}$. These results suggested that the expression of $s a c B$ was almost 10 fold lower than that of the $\operatorname{sac} C$ gene, when it was expressed by its own promoter.

\section{Comparison of induced expression of $\operatorname{sac} B$ and sac $C$ genes in $E$. coli BL21}

As we expected, the previous experiments showed that the expression of $\mathrm{SacC}$ was more than $\mathrm{SacB}$ by its own promoter. Then we examined the $E$. coli (carrying plasmids for $s a c B$ and $s a c C$ in which the genes were cloned under $\mathrm{T} 7$ promoter) cultures were grown in M63 medium with glycerol or fructose till they reached $1 \mathrm{OD}$ at $\mathrm{A}_{600}$. IPTG $(400 \mu \mathrm{M})$ was added to the cells and harvested after $4 \mathrm{~h}$ of incubation at $37^{\circ} \mathrm{C}$. Addition of IPTG to the growing cultures of recombinant $E$. coli BL21 induced the expression of $s a c B$ or $s a c C$ 
genes from all plasmids (pLS3, pLSP13, pZS63 and pZSP62). The uninduced culture of E. coli (pLS3) had sucrase activity of $4.5 \mathrm{U} / \mathrm{mg}$, which after induced expression of $s a c B$ gene resulted in sucrase activity of $72.0 \mathrm{U} / \mathrm{mg}$ (Table.1). The uninduced cells carrying similar plasmid construct with sacC gene (pZS63) had a high level of sucrase activity $(25.6 \mathrm{U} / \mathrm{mg})$ which upon induction produced a very high level ( $>100$ fold) of sucrase activity $(2672 \mathrm{U} / \mathrm{mg})$. Similar experiment was carried out with the strains carrying pLSP13 and pZSP62. The uninduced cells carrying $s a c B$ gene had a low level of sucrase activity $(1.9 \mathrm{U} / \mathrm{mg}$ ) but after induction showed a ten-fold increase in sucrase activity $(19.0 \mathrm{U} / \mathrm{mg})$. In contrast, the uninduced cells carrying sacC gene had sucrase activity of $12.8 \mathrm{U} / \mathrm{mg}$, which after induction resulted in more than 100-fold increase in sucrase activity. These results supported that the $\mathrm{sacC}$ gene responded better than the $s a c B$ gene, in the presence or absence of IPTG expression.

\section{Isolation of sucrase negative mutant of $Z$. mobilis}

A highly stable extracellular levansucrase, extracellular sucrase and intracellular sucrase mutant (SNM10) of Z. mobilis strain B-806 was isolated after NTG mutagenesis $(50 \mu \mathrm{g} / \mathrm{ml}$ for 45 $\min$ at $30^{\circ} \mathrm{C}$ ) from the strain LS1A (Kannan et al., 1998). It was repeatedly sub cultured in glucose medium and plated on RM agar plates. The cellular extracts of the randomly selected colonies were subjected to zymogram analysis for the detection of sucrase activity. Some of the isolate did not produce the sucrase band corresponding to $\mathrm{SacA}, \mathrm{SacB}$ and $\mathrm{SacC}$ and it was designated as SNM 1-10. Among 10 isolates, one of the isolate was taken for further studies. For confirming the stability of the SacA, SacB and SacC mutation, the strain (SNM10) was subcultured (3 times, $18 \mathrm{~h}$ growth period) in RM glucose medium, and then plated on RM agar plates. Randomly selected colonies were grown in RM glucose/fructose medium and the cellular fractions were analysed on native -PAGE and by zymogram staining (data not shown). None of the culture showed any reversion of the SacA, SacB and SacC mutation. As this strain was derived from the strain LS1A, the cellular fraction did not exhibit sucrase band corresponding to levansucrase (SacB) and intracellular sucrase (SacA). Therefore, the mutant LS1A was phenotypically defective for the synthesis of levansucrase and intracellular sucrase. The novel complete sucrase negative mutant SNM10 was phenotypically defective for the synthesis of all sucrases. We used this mutant (SNM10) for the expression of each plasmid encoded sucrase genes in Z. mobilis.

\section{Expression of sucrsae genes in $E$. coli and $Z$. mobilis}

We examined the effect of plasmid encoded sucrase synthesis in E. coli and different sucrase mutants of $Z$. mobilis. The plasmid were transformed in to Z.mobilis as described in Material asnd Methods section. Table 2 shows the extracellular sucrase activities exhibited by extract of E. coli and Z. mobilis. Strain B-806 was expressing sucrase genes by chromosomal encoded but the mutants strains of $Z$. mobilis were expressing by plasmid encoded sucrase genes. Most of the extracellular sucrase activity (nearly $70 \%$ ) produced by $s a c C$ gene and remaining activity was produced by $s a c B$ gene in Z.mobilis, as well as the same result was also observed in $E$. coli strains. Previous experiments have shown that the $s a c C$ gene carrying $E$. coli strain caused dramatic increase in the functional expression. The same effect was observed in $E$. coli and recombinant $Z$. mobilis strains.

Table 1 - Comparison of induced expression of sacB and sacC genes in E. coli BL21.

\begin{tabular}{l|r|r|r}
\hline \multirow{2}{*}{$\begin{array}{c}\boldsymbol{E} \text {. coli } \boldsymbol{B L 2 1} \text { strain } \\
\text { carrying the plasmid }\end{array}$} & $\begin{array}{c}\text { Name of the gene } \\
\text { expression }\end{array}$ & Sucrase activity $\mathbf{U} / \mathbf{m g}$ & Sucrase activity U/mg \\
\hline & & Un induced & Induced \\
\cline { 3 - 4 } pLS3 & sacB & 4.5 & 72.0 \\
pLSP13 & sacB & 1.9 & 19.0 \\
pZS63 & sacC & 24.6 & 2672.0 \\
pZSP62 & sacC & 12.8 & 1948.0 \\
\hline
\end{tabular}


Table 2 - Expression of plasmid encoded sucrase genes in E. coli and sucrase mutants of Z. mobilis

\begin{tabular}{l|c|c|c|r}
\hline Strains & $\begin{array}{c}\text { Basal level expression } \\
\text { Without plasmid } \\
\text { Sucrose hydrolysing } \\
\text { Activity (U/mg) }\end{array}$ & $\begin{array}{c}\text { Basal level expression } \\
\text { plus } \\
\text { SacB (pLSP13) } \\
\text { Levan forming } \\
\text { activity (U/mg) }\end{array}$ & $\begin{array}{c}\text { Basal level expression } \\
\text { plus } \\
\text { SacC (pZSP62) } \\
\text { Sucrose hydrolysing } \\
\text { Activity (U/mg) }\end{array}$ & $\begin{array}{c}\text { Total (Basal level } \\
+ \text { SacB + SacC } \\
\text { Levan forming } \\
\text { activity+ Sucrose } \\
\text { hydrolysing Activity } \\
\text { (U/mg) }\end{array}$ \\
\hline B-806 & 5.9 & $5.9+2.0$ & & 11.9 \\
LS1 & 3.9 & $3.9+2.15$ & $3.9+2.15+4.2$ & 10.25 \\
LS1A & 3.8 & $3.8+2.0$ & $3.8+2.0+4.1$ & 9.9 \\
SNM10 & 0.0 & $0+2.25$ & $0+2.25+4.3$ & 6.8 \\
\hline
\end{tabular}

We successfully introduced sucrase genes for synthesis of sucrase in wild type and sucrase negative mutants by expressing the $Z$. mobilis genes encoding $s a c B$ and $s a c C$ separately. Under the control of the each gene promoter, the specific activities of these two enzymes ranges from 2.0 to $4.3 \mathrm{U} / \mathrm{mg}$ (Table 2). However, both the genes were expressed successfully in all strains. The level of expression of the enzymes by plasmids was considerably higher than the levels of expression observed in chromosomal encoded. The difference between the levels of expression may be a function of a plamid copy number and of transcript coupled with and protein size and stability.

\section{Transcriptional analysis of $s a c B$ and $s a c C$ genes} According to the previous experiments, the $s a c C$ gene was expressed more stronger than $s a c B$ gene, irrespective of the medium and strains. we wanted to examine the same effect of $s a c B$ and $s a c C$ gene in E. coli as well as $Z$. mobilis by transcriptinal analysis. Hybridization of RNAs from Z. mobilis and E. coli (carrying $s a c B$ and $s a c C$ genes) cells, which were grown on glucose, fructose and sucrose was performed in order to determine whether enzyme induction was the result of transcriptional regulation of sucrase genes by carbon sources or the effect of promoter. The bands of 1.5 and $2.9 \mathrm{~kb}$ in size were also detected from cells grown on media containing glucose or fructose and sucrose and also E. coli cells grown minimal media. From these results, we concluded that $s a c B$ and $s a c C$ genes were expressed constitutively at the basal level (data not shown).

\section{Dot blot analysis}

In order to determine, if the high level expression of $\mathrm{SacC}$ was due to its strong promoter or was influenced by any carbon sources. Dot blot analysis of sucrases of mRNA levels in Z. mobilis cells grown on glucose, fructose and sucrose was performed. Surprisingly, the levels of sucrase mRNA of $Z$. mobilis cells grown on sucrose were found to be approximately three fold higher than the levels observed in cells grown on glucose and two fold higher than the levels observed in cells grown on fructose. Similar cases have been postulated in the gene expression of Z. mobilis and also depends on carbon source dependent regulation (Liu et al., 1992) It was of interest to determine if the increased level of transcript in sucrose grown cultures was also a general phenomenon for the expression of sucrase genes. Filters prepared with RNA samples were subjected to hybridization with $s a c B$ and $s a c C$ gene specific probes . Strong hybridization signals were detected for the RNA samples hybridized with $s a c C$ probes than $s a c B$ probes. Among the RNA samples from the cultures grown in different carbon sources, the maximum sucrase transcript was from the culture grown in sucrose (Figs. 2a and 2b). These experiments showed that the high amount of specific mRNA were present in sucrose grown culture than glucose and fructose grown cells.

\section{NORTHERN ANALYSIS}

To compare the expression of plasmid encoded $s a c B$ and $s a c C$ genes in $Z$. mobilis, and recombinant $E$. coli strains, the RNA samples from all cultures were subjected to northern hybridization analysis using specific probes for $s a c B$ and $s a c C$. While hybridized with $s a c B$ gene probe, strong signals were detected for the RNA samples of Z. mobilis and E. coli (pLS3) but relatively faint signal was observed for RNA samples from E. coli (pLSP13). Quantitative analysis of multiple hybridization experiments consistently showed two fold higher level of 
transcripts detected in Z. mobilis and E. coli (pLS3) than in E. coli (pLSP13). The $s a c B$ probe did not hybridize with $s a c C$ transcript from $E$. coli (pZS63) (Fig. 3a.). Similarly the $\operatorname{sacC}$ specific probe did not hybridize with the transcript from levansucrase clones i.e. E. coli (pLS3). The hybridization of $s a c C$ probe with the RNA isolated from $Z$. mobilis and E. coli was studied. The levels of sacC mRNA levels in E.coli (pZS63) was three fold higher than E.coli (pZSP62) and two folds higher than Z. mobilis (Fig. 3b). The SacC probe did not hybridize with transcript from E. coli (pLS3).

Comparison of the $s a c B$ and $s a c C$ transcripts, in the above strains revealed that the level of $s a c C$ transcript was approximately three fold higher than $s a c B$ transcript in Z. mobilis and also E. coli expressed $s a c B$ gene. Comparison of the transcript levels in the strains [ E. coli (pLS3) with (pZS63) and $E$. coli (pLSP13) with E. coli (pZSP62)] revealed that the $s a c B$ transcripts were much lower than the $\operatorname{sac} C$ transcript. These results suggested that the expression of $s a c B$ in either $Z$. mobilis or $E$. coli was much lower than the expression of $s a c C$ gene, probably due to inefficiency of $s a c B$ promoter. However, it is observed that extracellular sucrase ( $\mathrm{SacC})$ was unstable than extracellular levansucrase (SacB) (Sangiliyandi and Gunasekaran, 1998; Sangiliyandi et al., 1999a; Sangiliyandi et al., 1999b).

A high relative abundance of $s a c C$ specific transcripts might compensate for the instability of the Z. mobilis extracellular sucrase. Similar result was observed with the polycistronic mRNA of the Z. mobilis glf, zwf, edd, glk operon. Liu et al (1992) suggested that a high relative abundance of glk specific transcripts might compensate for the instability of the glucokinase. Eddy et al. (1989) reported that the ratio of gap message to $p g k$ message was approximately $5: 1$ ratio. The differential expression of gap and $p g k$ appears to be controlled at the mRNA level.

The pattern of codon usage in $\operatorname{sac} B$ gene was compared with two classes of genes known in $Z$. mobilis - highly expressed genes like pyruvate decarboxylase $(p d c)$, glucose-6-phosphate dehydrogenase $(z w f)$ and poorly expressed genes like intracellular sucrase $(\mathrm{SacA})$, acid phosphatase (PhoC) (Pond et al., 1989) and ligase (lig) (Gunasekaran et al., 1990a). The codon bias was calculated according to Shark and Conway (1992). It was found that the codons in $\operatorname{sacB}$ strongly correlated with codon usage and bias with poorly expressed genes. The three codons TGC, CTA and TAC were not used in $s a c B$. The codon TGT only was used for cys in $s a c B$. In $s a c B$ the preference of codons AAT, GAT, CAT and AAA were similar to low expressed genes. However, the use of codon $\mathrm{CAG}$ and TAT in $s a c B$ was similar to highly expressed genes. Thus, $s a c B$ could be classified as one of the low to intermediately expressed genes of $Z$. mobilis.

The relative abundance of the SacC enzyme in $Z$. mobilis might be due to high levels of $s a c C$ mRNA, a high rate of translation of the $s a c C$ message, or resistance of the sacC to proteolysis. Since most of the enzymes remain at high level at stationary phase, this factor alone can not be accounted for the high SacC activity. Therefore, the high level of extracellular sucrase results from an abundant sacC message, perhaps due to a combination of rapid transcription and significant mRNA stability. Stability of the sacC message might be imparted by the substantial stem-loop structures located both upstream and downstream of the $s a c C$ gene as suggested for several other $Z$. mobilis genes. In Northern blot analysis, increased expression of the $\mathrm{SacC}$ in cells grown on sucrose was proven to be the result of an increased transcription rate, compared with cells grown on glucose and fructose (Figs. 3a and 3b). Similar results were also observed in the gene expressions of $Z$. mobilis; carbon source dependent regulation (Liu et al., 1992). Considering the amount of transcripts, both the genes in the operon seemed to be expressed differently from each other, because of the existence of terminator sequence of $\operatorname{sac} B$ and sacC gene (Song et al., 1999). Similarly, Newbury et al. (1987) postulated that an intercistronic transcription terminator could act as a gene expression regulator in the analysis of a polycistronic malEFG operon of E. coli. Northern blot analysis suggested that the levels of sacC transcript were approximately three folds higher than $s a c B$ transcript in Z. mobilis as well as the $E$. coli (pZS63 or pZSP62). Thus, it is surprising that, the gene dosage can improve the hydrolysis of sucrose substrates during bioconversion to ethanol. Optimization of such a system by manipulating the growth conditions and genetically modifiying the host metabolism as well as development of ethanol retrieval technologies for the growth medium, could lead to production of ethanol by this organisms at an industrial level. 


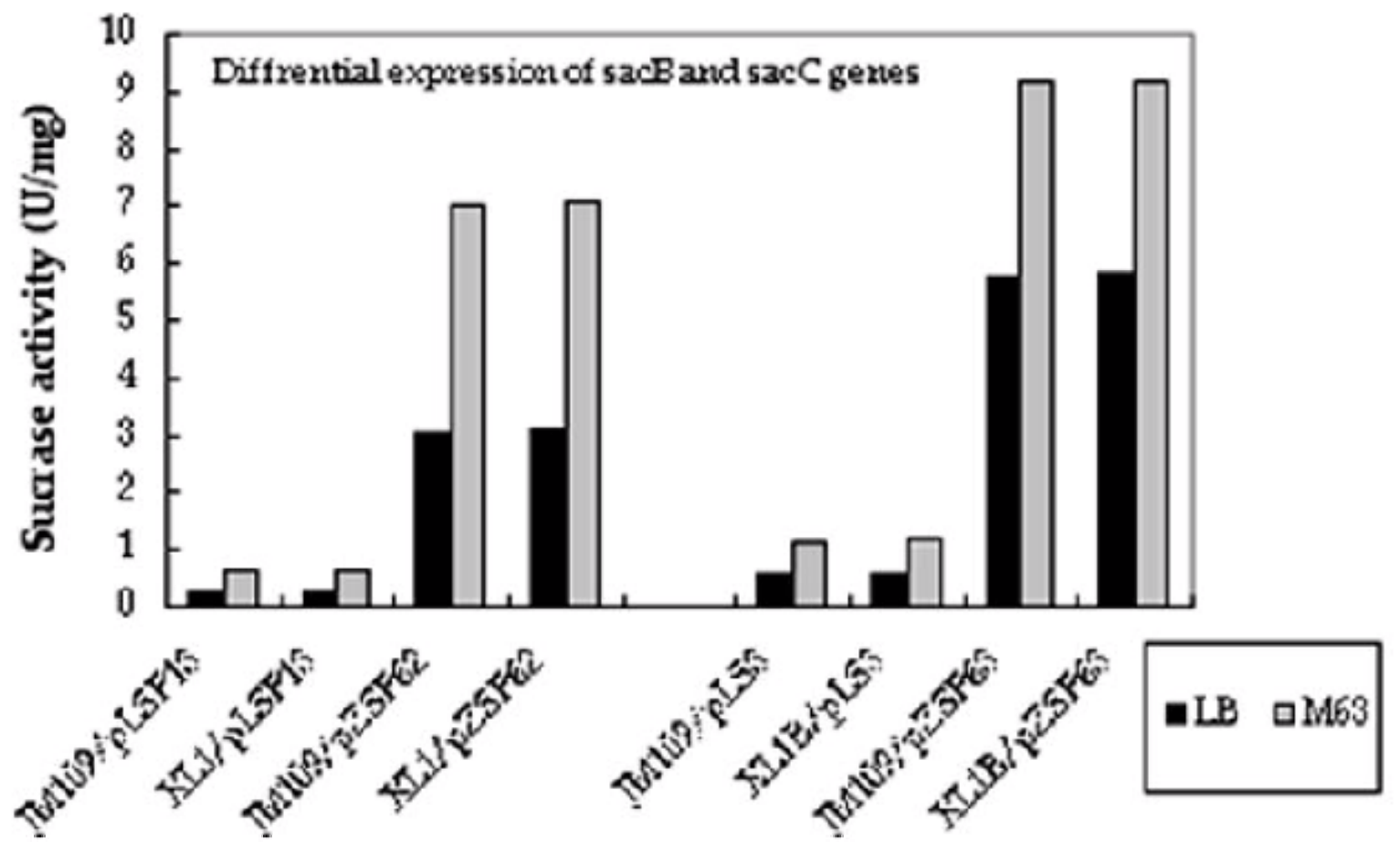

Figure 1 - Expression of $s a c B$ and $s a c C$ genes in E. coli.

The cultures of E. coli were grown in LB and M63 media and sucrase activity was assayed after $24 \mathrm{hrs}$.

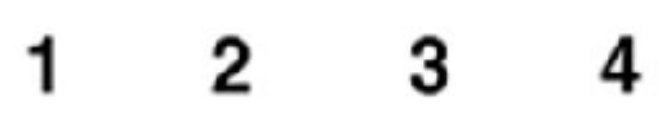

$\mathbf{2 A}$
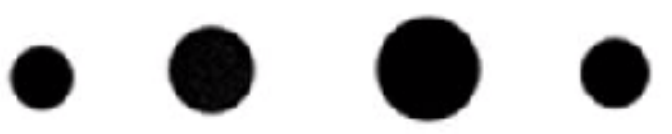

$2 B$
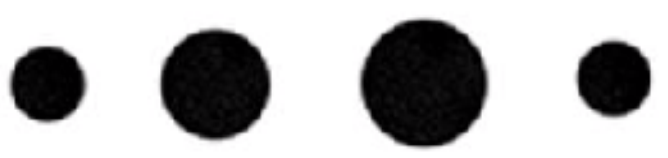

Figure 2 - Dot blot analysis of sucrase gene transcripts

Z. mobilis B-806 was grown to mid logarithmic phase in media glucose (1) or fructose (2) or sucrose (3) internal control (4) and total RNA was extracted. The $s a c B$ (A) and $s a c C$ (B) specific transcripts were identified using $s a c B$ and $s a c C$ genes probes respectively. 


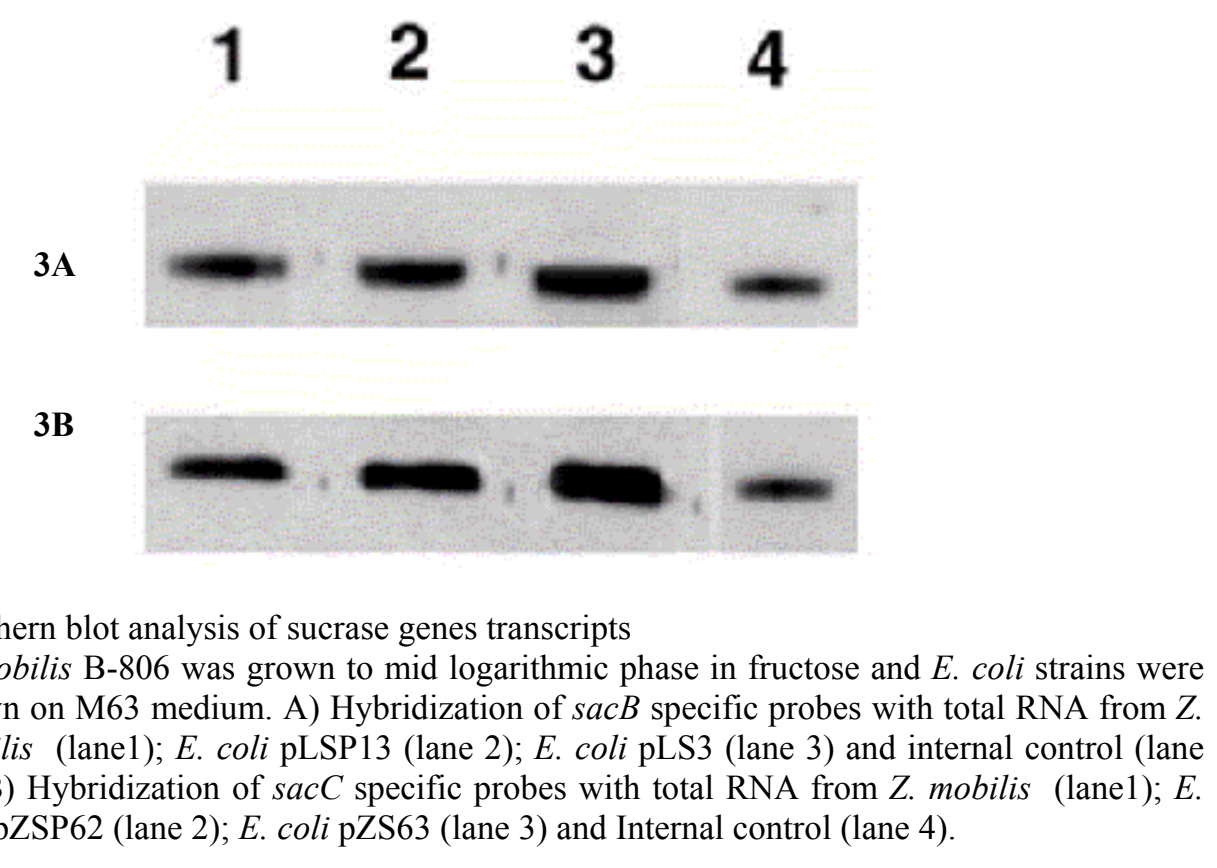

Figure 3 - Northern blot analysis of sucrase genes transcripts

Z. mobilis B-806 was grown to mid logarithmic phase in fructose and $E$. coli strains were grown on M63 medium. A) Hybridization of $s a c B$ specific probes with total RNA from $Z$. mobilis (lane1); E. coli pLSP13 (lane 2); E. coli pLS3 (lane 3) and internal control (lane 4). B) Hybridization of $s a c C$ specific probes with total RNA from Z. mobilis (lane1); E. coli pZSP62 (lane 2); E. coli pZS63 (lane 3) and Internal control (lane 4).

\section{ACKNOWLEDGEMENTS}

This work was supported by grants (No. 38/0912/EMR II) from CSIR, New Delhi and (No. SP/SO/A52/96) from DST, New Delhi. GS thanks UGC, New Delhi for their support with Senior Research Fellowship. We thank Mr. Arul Subramanian for critically reading this manuscript.

\section{RESUMO}

Os genes do $s a c B$ e do $\operatorname{sac} C$ que codificam o levansucrase e o sucrase extracellular respectivamente foram sub-clonados independentemente no pBluescript (número elevado de cópias) e no vetor ponte para $Z$. mobilis-E. coli, pZA22 (baixo número de cópias). A expressão destes genes foi comparada tanto em E. coli quanto em $Z$. mobilis. O nível da expressão do gene $s a c B$ em $E$. coli foi quase dez vezes menor do que a expressão do gene $\operatorname{sac} C$, independente do meio de cultivo ou da linhagem hospedeira. $\operatorname{Em} Z$. mobilis, a expressão dos genes $\operatorname{sac} B$ e $\operatorname{sac} C$ mostrou regulação dependente da fonte de carbono. Os níveis dos transcritos $s a c B$ e $s a c C$ estavam três vezes mais aumentados em células cultivadas em sacarose do que aquelas cultivadas em glicose/frutose. A análise por Northern blot revelou que o nível do transcrito $s a c C$ era 2-3 vezes maior do que aquele de $s a c B$. Esses resultados sugerem que a expressão do gene $s a c C$ foi mais pronunciada do que $s a c B$.

\section{REFERENCES}

Ait-Abdelkader, N.; DeCaro, A.; Guzzo, J.; Michael, G.P.F. and Baratti, J. C. (2000), The intracellular sucrase (SacA) of Zymomonas mobilis is not involved in sucrose assimilation. Biotechnol.Lett., 22, 461-467.

Arvanitis, N.; Pappas, K.M.; Kolios, G.; Afendra, A. S.; Typas, M. T. and Drainas, C. (2000), Characterization and replication properties of the Zymomonas mobilis ATCC10988 plasmids pZM01 and pZM02.Plasmid, 44, 127-37.

Ausubel, F. M.; Brent, M.; Kingston, R. E.; Moore, D. D.; Seidman, J. G.; Smith, J. A. and Struhl, K. (1984), Current protocols in molecular biology. New York : John Wiley and Sons Inc.

Chung, C. T. and Miller, R. H. (1988), A rapid and convenient method for the preparation and storage of competent bacterial cells. (1988). Nucleic. Acid Res., 16, 3580.

Eddy, C. K.; Mejia, J. P.; Conway, T. and Ingram, L. O. (1989), Differential expression of gap and pgk genes within the gap operon of Zymomonas mobilis. J. Bactriol., 171, 6549-6554.

Gunasekaran, P.; Karunakaran, T.; Cami, B.; Mukundan, A. G.; Preziosi, L. and Baratti, J. (1990a), Cloning and sequencing of the sac $A$ gene: Characterization of a sucrase from Zymomonas mobilis. J. Bacteriol., 172, 6727-6735. 
Gunasekaran, P.; Mukundan, G.; Kannan, T. R.; Velmurugan, S.; Ait-Abdelkader, N.; AlvarezMacarie E. and Baratti, J. (1995), The $s a c B$ and $s a c C$ genes encoding levansucrase and sucrase form a gene cluster in Zymomonas mobilis. Biotechnol. Lett., 17, 635-642.

Kannan, R.; Pitchaimani, K.; Gunsekaran, P.; AitAbdelkader, N. and Baratti, J. (1995), Overexpression extracellular sucrase (SacC) of Zymomonas mobilis in Escherichia coli. FEMS Microbiol. Lett., 133, 29-33.

Kannan, T. R.; Mukundan, A. G.; Ait-Abdelkader, N.; Augier-Magro, V.; Baratti, J. and Gunasekaran, P. (1995), Molecular cloning and characterization of the extracellular sucrase gene ( $\mathrm{sacC}$ ) of Zymomonas mobilis. Arch. Microbiol., 163, 195-204.

Kannan, T. R.; Sangiliyandi, G. and Gunasekaran, P. (1998), Improved ethanol production from sucrose by a mutant of Zymomonas mobilis lacking sucrases in immobilized cell fermentation. Enz. Microbial. Technol., 22, 179-184.

Liu, J.; Barnell, W. O. and Conway, T. (1992), The polycistronic mRNA of the Zymomonas mobilis glfzwf-edd-glk operon is subjected to complex transcript processing. J. Bacteriol., 174, 2824-2833.

Lowry, O. H.; Rosebrough, N. J.; Farr, A. L. and Randall, R. J. (1951), Protein measurement with Folin-phenol reagent. J. Biol. Chem., 193, 265-275.

Lyness, E. W. and Doelle, H. W. (1983), Levansucrase from Zymomonas mobilis. Biotechnol. Lett., 5, 345-350.

Mortatte, M. P. L.; Sato, H. H. and Park, Y. K. (1983), Introduction and some characteristics of sucrosehydrolyzing enzymes from Zymomonas mobilis. Biotechnol. Lett., 5, 518-526.

Newbury, S. F. and Smith, N. H. (1987), Differential mRNA stability controls relative gene expression within a polycistronic operon. Cell, 51, 1131-1143.

O'Mullan, P. J.; Chase, T. and Eveleigh, D. E. (1992), Purification and some properties of extracellular invertase from Zymomonas mobilis. Appl. Microbiol. Biotechnol., 38, 341-346.

Pond, J. L.; Eddy, C. K.; Mackenzie, K. F.; Conway, T.; Borecky, D. L. and Ingram, L. O. (1989), Cloning, sequencing and characterization of principal acid phosphate, the Pho $\mathrm{C}$ product, from Zymomonas mobilis. J. Bacteriol., 171, 767-774.

Preziosi, L.; Michael, G. P. F. and Baratti, J. (1990b), Characterization of sucrose hydrolyzing enzyme of Zymomonas mobilis. Arch. Microbiol., 153, 181-186.

Rogers, P. L.; Lee, K. J.; Skotnicki, M. L. and Tribe, D. E. (1982), Ethanol production by Zymomonas mobilis. Adv. Biochem. Engg. Biotechnol., 23, 37-84.

Sambrook, J.; Fritsch, E. F. and Maniatis, T. (1989), Molecular cloning: a laboratory manual. $2^{\text {nd }}$ ed. Cold Spring Harbor Laboratory. New York : Cold Spring Harbor.
Sangiliyandi, G. and Gunasekaran, P. (1998), A simple method for purification of thermostable levansucrase of Zymomonas mobilis from a recombinant Escherichia coli. J. Microbiol. Meths., 33, 153-156.

Sangiliyandi, G.; Raj, C. R. and Gunasekaran, P. (1999a), Elevated temperature and chemical modification selectively abolishes levan-forming activity of levansucrase of Zymomonas mobilis. Biotechnol. Lett., 21, 179-182.

Sangiliyandi, G.; Kannan, T. R.; Raj, C. R. and Gunasekaran, P. (1999b), Separation of levan formation and sucrose hydrolysis catalysed by levansucrase of Zymomonas mobilis using in-vitro mutagenesis. Braz. Arch.Biol.Techn., 42, 375-379.

Sangiliyandi, G. and Gunasekaran, P. (2000), A simple method for the purification of over-expressed extracellular sucrase of Zymomonas mobilis from a recombinant Escherichia coli. Biotechnol. Lett., 22, 1059-1062.

Sangiliyandi, G. and Gunasekaran, P. (2000), Polymerase and hydrolase activities of Zymomonas mobilis levansucrase separately modulated by in-vitro mutagenesis and elevated temperature. J. Process. Biochem., 36, 543-548.

Shark, B. K. and Conway, T. (1992), Cloning and molecular characterization of the DNA ligase (lig) from Zymomonas mobilis. FEMS Microbiol. Lett., 96, 19-26.

Song, K. B.; Seo, J. W. and Rhee, S. K. (1999), Transcriptional analysis of levU operon encoding saccarolytic enzymes and two apparent genes involved in aminiacid biosynthesis in Zymomonas mobilis. Gene, 232, 107-114.

Suzuki, Y.; Seikya T. and Hayashi, K. (1991), Allelespecific polymerase chain reaction: a method for amplification and sequence determination of a single component among a mixture of sequence variants. Anal. Biochem., 192, 82-84.

Swings, J. and De Ley, J. (1977), The biology of Zymomonas. Bacteriol Rev., 41, 1-46.

Viikari, L. and Gisler, R. (1986), By-products in the fermentation of sucrose by different Zymomonas strain. Appl. Microbiol. Biotechnol., 23, 240-244.

Viikari, L. (1984) Formation of levan and sorbitol from sucrose by Zymomonas mobilis. Appl. Microbiol. Biotechnol., 19, 252-255.

Yanase, H.; Iwata, M.; Nakahiagashi, R.; Kita, K.; Kato, N. and Tonomura, K. (1992), Purification, crystallization and properties of the extracellular levansucrase from Zymomonas mobilis. Biosci. Biotech. Biochem., 56, 1335-1337.

Received: September 11, 2002; Revised: July 28, 2003; Accepted: February 27, 2004. 